\title{
Firms' distance to the European productivity frontier
}

\author{
Dolores Añón Higón ${ }^{1}$ (D) Juan A. Máñez ${ }^{1}$ (D) - María E. Rochina-Barrachina ${ }^{1}$ (D) \\ Amparo Sanchis ${ }^{1}$ (D) Juan A. Sanchis ${ }^{1}$ (D)
}

Received: 5 July 2020 / Revised: 17 October 2021 / Accepted: 7 January 2022 /

Published online: 18 February 2022

(c) The Author(s) 2022

\begin{abstract}
In this article we explore the factors contributing to reduce the distance of laggard firms to the European frontier, focusing on institutional factors. To characterize Total Factor Productivity frontier firms within industries for the European Union we use firm level data from AMADEUS for the period 2003-2014. Our findings provide evidence on the importance of governance quality and easiness in getting credit in explaining the distance of laggard firms to the European productivity frontier. We also find that other factors at the country level -tertiary education, R\&D stock, and trade openness- and at the firm level -size, age, and capital-intensity- influence the distance of laggards to the frontier. In addition, we examine the role of the Great Recession in moderating the contribution of all these factors to reduce firms' distance to the European productivity frontier.
\end{abstract}

Keywords Total Factor Productivity $\cdot$ Frontier firms $\cdot$ Laggard firms $\cdot$ Institutional factors · Great Recession - European Union countries

JEL Classification D24 · O47 · O52

María E. Rochina-Barrachina

erochina@uv.es

Dolores Añón Higón

m.dolores.anon@uv.es

Juan A. Máñez

jamc@uv.es

Amparo Sanchis

sanchisa@uv.es

Juan A. Sanchis

sanchisl@uv.es

1 Department of Applied Economics II and ERICES, Faculty of Economics (Universitat de València), Avda. Tarongers, s/n, 46022 Valencia, Spain 


\section{Introduction}

In recent decades Europe has suffered from a trend decline in productivity growth, a phenomenon that precedes the Great Recession (Ridao-Cano \& Bodewig, 2018). This so-called "productivity puzzle" has been accompanied by wide and persistent productivity growth dispersion among EU countries, which has raised concerns about rising income differentials and long-term cohesion across member states. As a result, some studies have explored the evolution of these productivity differences in the EU over time and the extent to which they have been growing or shrinking (Färe et al., 2006; Sondermann, 2014; Villaverde \& Maza, 2008). A common feature of this literature has been the use of aggregated or industry level data. However, the slowdown and the widening dispersion in productivity cannot be fully understood without adopting a firm-level perspective (Bartelsman et al., 2013; Hsieh \& Klenow, 2009; Restuccia \& Rogerson, 2008). In the EU these trends may be the result of an increasing divergence between a small number of companies with high productivity (frontier firms), perhaps located in a very few EU countries, and many laggard firms unable to reduce the distance with frontier firms (Andrews et al., 2016). ${ }^{1}$ Nevertheless, little is known about the characteristics of firms belonging to the EU productivity frontier, as compared to non-frontier or laggard firms, and the factors explaining the distance of laggards to the European frontier, and in particular regarding the contribution of institutional factors to reduce this technological distance.

The aim of this paper is to fill this gap by characterizing firms at the EU productivity frontier and providing evidence on the institutional factors that contribute to reduce the distance between laggards and the most productive firms in their industry at the European level. First, using firm level data from the AMADEUS dataset for the period 2003-2014, we estimate Total Factor Productivity (TFP henceforth) at the firm level. We then focus on identifying the frontier firms at the EU level - defined as the top most productive $5 \%$ of firms within each two-digit sector but pooled across EU countries - and compare them with non-frontier (or laggard) firms. Secondly, we explore the factors determining the distance of laggards to their technological EU frontier. In particular, we focus on exploring how institutional factors at the country level contribute to reduce the technological distance of laggards to the within-industry EU frontier firms, controlling for other factors at the firm and country levels, and also for productivity improvements of the frontier. The key institutional factors considered in this study are Governance Quality and Easiness in Getting Credit at the country level. The main reasons to focus on these two institutional factors are the following. On the one hand, governance quality may provide incentives and opportunities for better firms' performance, by shaping firms' operating environment (Agostino et al., 2020; Lasagni et al., 2015; Rios \& Gianmoena, 2020). On the other hand, we aim at contributing to the recent debate about capital misallocation to less efficient firms hindering convergence of laggard firms to the

\footnotetext{
1 The rising productivity dispersion and slow technology diffusion are not the only causes of the aggregate slowdown in productivity. Other explanations lie in the increasing resource misallocation (Gopinath et al., 2017) and the decline in business dynamics (Decker et al., 2016).
} 
technological frontier in the EU (Dias et al., 2014; Gopinath et al., 2017). Thirdly, we investigate the role of the Great Recession in moderating the effect of all these factors, and especially of the key institutional factors, by considering two different sub-periods, namely, the period prior to the last financial crisis, which we call the pre-recession period, 2003-2007, and the recession period, 2008-2014. We are particularly interested in answering two research questions. The first one is whether the contribution of governance quality to reduce the distance of laggards to the EU technological frontier has been stronger during the years of recession, as compared to the pre-recession period. The second one is whether efficiency in capital allocation among firms has been more relevant for the convergence of laggard firms to the EU technological leaders during the recession period, as compared to the pre-recession years.

The contribution of this paper to the related literature is threefold. First, our study provides new evidence using firm level data to the scarce existing literature on the characteristics of firms operating at the productivity frontier, as compared to nonfrontier or laggard firms, and on the factors explaining the distance of laggards to the technological frontier. In particular, our focus is on the European Union, which we consider an integrated market, and use a microeconomic approach to estimate firms' productivity and to derive the "EU frontier firms". Our analysis thus contributes to the understanding of the factors behind productivity industry dispersion among firms in Europe. Although a number of papers have analyzed productivity divergence and the convergence of laggards to the frontier firms (Adalet McGowan et al., 2017; Andrews et al., 2016; Bartelsman et al., 2008), to our knowledge there is no prior study attempting to first, identify the EU frontier firms and, second, to study the determinants of the distance of laggards to the EU technological frontier. Secondly, we focus on exploring the relevance of institutional factors at the country level in explaining the technological distance of laggards to the frontier firms. These factors have been analyzed in studies at the country level, but their contribution to reduce laggards' technological distance to the EU frontier has not been explored. Thirdly, by investigating the moderating role of the Great Recession on the factors explaining the technological distance of laggards to the EU frontier firms, we contribute to the understanding of the importance of financial market conditions and the competitive pressure faced by firms for the diffusion of knowledge and technological change among firms.

Our main findings may be summarized as follows. First, our results suggest the importance of institutional factors at the country level such as governance quality and easiness in getting credit in explaining firms' productivity dispersion. Second, the effect of these institutional factors varies over the business cycle. In particular, governance quality significantly contributes to reduce the distance of laggards to the technological frontier, especially during the recession period, whereas easiness in getting credit significantly contributes to increase the productivity gap between laggards and frontier firms during the pre-recession period, but shows a weaker effect in explaining divergence during the recession years. The latter result is consistent with the existence of capital misallocation, especially during the pre-crisis years. Third, our results also show that, at the country level, tertiary education, R\&D stock, and trade openness contribute to narrow the distance to the frontier, and that, at the 
firm level, larger, older and more capital-intensive firms are closer to the productivity frontier. These findings are robust to controlling for the intertemporal shift of the technological frontier.

The rest of the paper is organized as follows. Section 2 reviews the literature and presents the hypotheses to be tested. Section 3 presents the data and describes the measurement of firms' productivity. Section 4 provides a descriptive analysis and careful characterization of the EU frontier firms versus non-frontier (or laggard) firms. Section 5 presents a regression analysis of the determinants of the distance of laggards to the technological frontier firms (or firms' TFP gaps), focusing on institutional factors at the country level. Finally, Sect. 6 concludes.

\section{Literature review and hypotheses}

There is a renewed interest in understanding the factors behind productivity dispersion and, in particular, in the drivers of productivity convergence among EU countries (Ridao-Cano \& Bodewig, 2018). There are two main perspectives in the study of productivity convergence to the frontier: the macroeconomic and the microeconomic approach. In the former, the unit of analysis is either the country or the region (Barro \& Sala-i-Martín, 1992) and the objective is to identify the frontier at the country or region level, and to test whether productivity growth in other territories is related to the existing gap to the frontier (see Acemoglu et al., 2006; Aghion et al., 2008; Amable et al., 2010; Griffith et al., 2004a; Kneller \& Stevens, 2006; Sala-iMartín, 1996; among others). Under this approach, it is assumed that all firms in a given region converge towards the technological frontier, disregarding heterogeneity across firms (Jovanovic, 1982; Melitz, 2003).

The microeconomic approach, instead, aims at overcoming some of these limitations, and especially the heterogeneity across firms (Acemoglu et al., 2007; Alvarez \& Crespi, 2007; Andrews et al., 2015; Bartelsman et al., 2008, 2015; Ding et al., 2016; Griffith et al., 2004b). The unit of analysis is the firm, and it is based on the identification of a best-practice frontier firm (or group of firms) reflecting the most advanced technology within an industry and country (or groups of countries). In light of these considerations, micro data for all (potentially relevant) countries within a given geographical area or development level is useful for identifying the relevant frontier, which may differ from the national frontier. The scarce literature analyzing firm level data in a multi-country analysis uses a small number of countries to identify the "global" frontier firms. For example, Bartelsman et al. (2008) focus on the United States and five European economies. Iacovone and Crespi (2010) and Van der Wiel et al. (2012) analyze Mexico and The Netherlands, respectively, and use data from Bartelsman et al. (2008) to identify the global frontier. Two exceptions to these studies are Andrews et al., $(2015,2016)$, who analyze the global frontier considering a sample of 23 OECD countries over the period 2001-2009, and 24 OECD countries over the period 1997-2014, respectively.

In this paper we use a microeconomic approach to derive the "EU frontier firms", considering the EU as a well-defined area to be analyzed, that is, as a group of countries that are linked through strong political, economic and trade relationships. As 
stated by Gill and Raiser (2012) in their World Bank's report, Europe may be considered as a "convergence machine" given the remarkable results that has achieved in terms of economic growth and convergence during decades. Considering the EU as an integrated market, our aim in this paper is to identify the technological frontier firms within the EU, examine their characteristics vis à vis non-frontier firms or laggards, and analyze the factors explaining the distance of laggards to the frontier firms, with a special focus on the role of relevant institutional factors at the country level.

The literature dealing with productivity dispersion has considered a number of factors, which can be mostly classified as either microeconomic -those linked to firms' characteristics-, and macroeconomic, country-level or context factors. In the latter group, the quality of institutions stands as a crucial factor (Agostino et al., 2020; Gogokhia \& Berulava, 2021; Lasagni et al., 2015). In the light of the focus of this study, in what follows we pay attention to those works that have dealt with a variety of channels through which institutional quality may affect firms' productivity.

Institutional quality may be captured in a number of different ways, and in this study we use two measures. The first one, which is standard in the literature, consists in the construction of a governance quality index at the country level (Kaufmann et al., 2010; Mimicopoulos et al., 2007). We follow Kaufmann et al. (2010) and consider governance quality as a key factor characterizing countries' quality of institutions. The governance quality index rests in the nature of the legal and political systems of a country, including the quality of public services, the trustworthiness of the legal system, rule of law and control of corruption. There are a number of reasons to expect a positive relationship between the quality of governance at the country level and firms' productivity. First, high quality of governance is likely to be associated with a strong legal system that lowers transaction costs by securing property rights and enforcing contracts, encouraging business activities and the accumulation of human and physical capital (Acemoglu et al., 2002; Rodrik et al., 2004), and also with a strong judicial system and effective bankruptcy regulations allowing the exit of inefficient firms and, therefore, improving resource allocation, and in turn, productivity (OECD, 2017). Secondly, the quality of governance may increase productivity by increasing the efficiency of public investment. There is evidence linking good institutions with the returns on public goods investment at the regional European level (Crescenzi et al., 2016). Finally, higher quality of governance may reinforce antitrust implementation, minimize barriers of entry for new firms, and reduce the privileges of incumbent firms, all of which is likely to boost productivity by facilitating the replacement of less productive and inefficient firms and technologies. There is, for instance, evidence documenting that corruption is linked to barriers of entry (Campos et al., 2010), lower entrepreneurship (Nistotskaya et al., 2015) and reduced innovation performance (Rodríguez-Pose \& Di Cataldo, 2015). Studies by Lasagni et al. (2015) for Italian firms and Agostino et al. (2020) for European firms provide strong evidence of a positive impact of local governance quality on firms' productivity using a similar index of institutional quality to the one used in our study. In addition, Gogokhia and Berulava (2021) calculate an index of business environment reforms by country and size of locality and show that it is an important 
external predictor of firms' labor productivity in transition economies. Moreover, when considering the heterogeneous effects of the dimensions of the business environment index, they find that the political stability/legal environment component (which considers political instability, corruption, etc.) has a direct effect on firms' productivity.

The second measure of institutional quality at the country level that we use in this study relates to the quality of financial markets and it is captured by an indicator of the easiness in getting credit. ${ }^{2}$ On the one hand, a developed capital market may play a crucial role in reducing the vulnerability of the economy to adverse financial shocks (OECD, 2017), and to the probability of suffering abrupt breaks of capital inflows (Honing, 2008), allowing for more sustainable FDI inflows (Alguacil et al., 2011). The access of firms to financial markets has been considered as an important institutional factor that may contribute to reduce the technological gap, by facilitating firms' access to financial resources to fund their investments (Andrews et al., 2015). Financial systems are crucial in helping credit-constrained firms to implement and commercialize new ideas, which, in turn, may raise their productivity. Easy access to credit also allows funds to flow towards young innovating firms, facilitating their growth (Andrews et al., 2015). In this line, Gogokhia and Berulava (2021) find that another component of the business environment index, a business/economic regulatory environment index (which includes, among other factors, access to finance), also has a direct effect on enhancing firms' productivity. On the other hand, an excess of financial resources or unusually easy access to credit could also be associated with the possibility of misallocation of capital to less efficient firms, helping their survival and so contributing to increase the distance of laggards to the technological frontier (Dias et al., 2014; Gopinath et al., 2017). Therefore, whether easiness in getting credit contributes to reduce or to increase the distance of laggards to the productivity frontier is at the end an empirical matter.

Based on the above discussion, we formulate the following two hypotheses:

H1 Quality of governance at the country level positively contributes to reduce the distance of laggard firms to the technological frontier.

H2 Easiness in getting credit at the country level may contribute to reduce or to increase the distance of laggard firms to the technological frontier.

In addition, since our data covers the period 2003-2014, this allows us to distinguish between two sub-periods corresponding to before and after the world economic crisis known as the Great Recession. In this respect, our study aims to shed light on whether the crisis period has strengthened or weakened the effects of our key institutional factors in explaining the distance of laggard firms to the

\footnotetext{
${ }^{2}$ The indicator of the easiness in getting credit that we use in this study is obtained from the World Bank dataset Doing Business. This indicator tries to capture both the strength of the credit system and the effectiveness of the financial system in facilitating lending in a country, as explained in Sect. 3.
} 
technological frontier. ${ }^{3}$ This aim gives rise to two additional hypotheses that we explain in what follows.

A number of studies have documented that the quality of institutions is related to firms' economic performance during the Great Recession in Europe. Recently, Sondermann (2018), Ezcurra and Rios (2019) and Rios and Gianmoena (2020) find that the quality of institutions and, in particular, the quality of government, is one of the most robust drivers of firms' employment resilience in a recessive period. In these studies, government quality is found to contribute to reduce the intensity of shocks by improving policy responses and, thus, minimizing vulnerability. Also somehow related, the results in Agostino et al. (2020) support the idea that better institutions might particularly favor weaker firms. In this paper, they associate weaker firms with SMEs. In our case, in a similar way, we can associate a period of recession with a further weakening of firms, which most likely increases the relevance of the quality of institutions to reduce uncertainty and transaction costs.

Differently, some other studies provide evidence about a negative relationship between the easiness in getting credit and a firm's productivity in the pre-recession period. For instance, the study of Cette et al. (2016) provides evidence, for a sample of European countries, of a link between low interest rates - and abundant credit-, and low productivity growth in the pre-recession period, consistent with the idea of pre-recession misallocation of capital (suggesting that capital was allocated to less productive firms). Evidence in this direction can be also found in the work of Gopinath et al. (2017), who analyze firm level data extracted from AMADEUS to document some deterioration in the efficiency of capital allocation across Spanish manufacturing firms between 1999 and 2012. They show how a decline in the real interest rate (that is, a decline in the cost of capital) directed capital inflows to less productive firms under financial frictions (and adjustment costs). They also find that, similarly to Spain, in Italy (1999-2012) and Portugal (2006-2012) there was also a decline in productivity probably related to capital misallocation. In addition, Dias et al. (2014) find that allocative efficiency in the Portuguese economy strongly deteriorated over 1996-2011, and that there was an important role for capital distortions, implying that the financial sector might have contributed to the survival of relatively inefficient firms. If this was the case during the pre-recession period, the reallocation of capital towards more productive firms during the recession -a period of more restricted credit provision- could offset the increase in the distance of laggards to frontier firms associated with an excessive and indiscriminate credit provision during the pre-recession period.

Consequently, we may expect the Great Recession starting in 2008 to play a moderating role regarding the impact of institutional factors such as governance quality

\footnotetext{
3 The paper by Castellani et al. (2019) has also uncovered some changes in labor productivity gaps during the same crisis period. In particular, they document the evolution of productivity gaps between US and EU firms from 2004 to 2012. They use data from the EU industrial R\&D scoreboard matched with ORBIS and, hence, their sample mainly comprises large firms. They find that this productivity gap has worsened during the crisis period, the reason being that EU firms have been relatively more hit in their capacity to transform R\&D investments into productivity, as compared to US firms.
} 
and easiness of getting credit on firms' productivity dispersion. According to the above discussion, we formulate the following two hypotheses:

H3 The contribution of governance quality to reduce the distance of laggard firms to the technological frontier is stronger during recession years.

H4 During pre-recession years, easiness in getting credit contributes to increase the distance of laggard firms to the technological frontier (capital misallocation). However, this effect may be softened or reversed during recession years.

The four hypotheses are tested using regression techniques.

\section{Data and measurement of productivity}

The firm level data we use in our analysis are drawn from AMADEUS, a database providing firms' balance sheet information, such as value added, assets, age, and the number of employees, for all EU countries. We use this information to estimate TFP at the firm level in a cross-country setting.

Following Arnold et al. (2008), Gal (2013), and Andrews et al. (2015), in order to obtain better coverage and a more balanced sample we focus on the set of firms with more than 20 employees. ${ }^{4}$ Thus, the resampling procedure targets the size-sector-country distribution of the true population of firms with at least 20 employees. ${ }^{5}$ Further, to ensure that the computation of TFP is feasible for the largest possible number of firms we follow Gal (2013), who suggested an imputation methodology that improves the original coverage of AMADEUS. Our working sample is largely consistent with that in Gal (2013) for the overlapping countries. In addition, currency conversion based on PPPs and deflation are applied to ensure comparability of productivity measures across countries and over time.

The data we analyze correspond to the period 2003-2014. The coverage of EU Member States is subject to data availability in AMADEUS. Thus, our data cover 23 EU Member States. Cyprus and Lithuania are excluded, as there is no information for these two countries. Luxembourg, Malta, and Latvia are also excluded due to an insufficient number of observations. The industry classification is based on NACE Rev. 2, limited to the market sectors and excluding agricultural, mining, real estate and financial sectors, since these latter sectors are more prone to issues in accurately

\footnotetext{
4 Arnold et al. (2008) pointed out that AMADEUS does not have a satisfactory coverage of firms with less than 20 employees. Gal (2013) highlighted the potentially lower quality of data for smaller firms in ORBIS. Also, for ORBIS Andrews et al. (2015) emphasized similar problems of data coverage and quality, and also excluded firms with less than 20 employees.

5 A drawback of AMADEUS (and ORBIS) is that it is a selected sample of larger and more productive firms, which tends to result in smaller and younger firms being under-represented in some economies. Hence, the analysis of the effects of the determinants of the distance to the frontier in Sect. 5 should be interpreted as lower bound effects, to the extent that the most laggard firms are likely to be under-represented in the analysis.
} 
measuring output and they are more affected by lack of information. ${ }^{6}$ As for the financial sector, since AMADEUS does not generally include banks, the coverage would not be representative of this sector at the European level and, therefore, it is excluded. After cleansing the data from missing values in relevant variables and keeping company accounts with valid information for our analysis, we have a sample of 1,123,360 observations, corresponding to 207,689 firms. We follow KalemliOzcan et al. (2015) and Andrews et al. (2016) criteria for filtering our data.

In order to estimate productivity, we first estimate a Cobb-Douglas value added production function following the methodology proposed by Wooldridge (2009) and using the demand for intermediate materials as a control function (see Levinshon and Petrin, 2003). We consider the log version of the production function as follows:

$$
y_{i c p t}=\beta_{0 p}+\beta_{L p} l_{i c p t}+\beta_{K p} k_{i c p t}+\omega_{i c p t}+\eta_{i c p t}
$$

where $i$ denotes firm, $c$ refers to country, $p$ denotes 2-digit industry and $t$ is time period, $y_{i c p t}$ is the natural $\log$ of value added, $l_{\text {icpt }}$ is the natural $\log$ of labor, and $k_{i c p t}$ is the natural log of capital. As for the unobservables, $\omega_{i c p t}$ is the firm productivity (not observed by the econometrician but observable or predictable by firms) and $\eta_{i c p t}$ is a standard i.i.d. error term that is neither observed nor predictable by the firm.

The production function in (1) is estimated separately for each two-digit industry $p$ but pooled across all countries, controlling for country and year fixed effects. This allows for technological differences across industries, while simultaneously facilitating both international and over time comparability of the resulting productivity levels. ${ }^{7}$ We obtain estimates of firms' TFP as the residuals from the estimated production functions:

$$
\widehat{\omega}_{i c p t}=y_{i c p t}-\widehat{\beta}_{L p} l_{i c p t}-\widehat{\beta}_{K p} k_{i c p t}
$$

where $\widehat{\omega}_{\text {ictp }}$ is the estimate of the $\log$ TFP for firm $i$ in country $c$, belonging to the 2-digit industry $p$ and period $t$. Appendix 1 describes in detail the procedure used to obtain TFP estimates using Wooldridge (2009) method. The estimated industry-specific input elasticities and the firms' mean TFP are shown in Table 7 in the Appendix. This table also reports the distribution of firms (and resulting observations) across industries. In Table 8 in the Appendix we report the distribution of firms and observations across countries.

\footnotetext{
${ }^{6}$ See Table 6 in Appendix 1 for the classification of industries used in our analysis. The industry classification is based on NACE Rev. 2, limited to the market non-farm/agricultural non-financial sectors (that is, excluding industries $\mathrm{A}, \mathrm{B}$, and $\mathrm{O}$ to $\mathrm{P}$ due to the lack of information).

${ }^{7}$ This assumption is crucial to properly define, in a homogeneous way, the composition of firms belonging to the EU frontier within each industry.
} 


\section{Descriptive analysis of EU frontier firms}

We use a microeconomic approach to derive the "EU frontier firms", considering the EU as a well-defined area to be analyzed. Following Andrews et al. (2016), for the construction of the productivity frontier we take a fixed number of firms per industry over the sample period. More specifically, frontier firms are identified using the top (most productive) $5 \%$ of the median number of firms across years within each two-digit industry. ${ }^{8}$ This definition allows frontier firms to change over time since we maintain fixed the number of firms at the frontier by industry (i.e., the median number of firms), not the set of frontier firms. It also allows the frontier size to vary across industries, and avoids potential problems that may arise as the coverage of firms by AMADEUS expands over time. Once the EU frontier firms for each two-digit industry have been identified, we first characterize the EU frontier firms (and compare them with non-frontier firms) and, then, analyze its composition by country of origin.

\subsection{A characterization of the EU frontier firms}

To analyze the EU frontier firms, we describe cross-sectional differences in key characteristics between EU frontier and non-frontier or laggard firms over a number of measurable dimensions. The dimensions considered include TFP (measured as described in Sect. 3), age, employment, value added, capital intensity, profits and wages per employee. A test for the difference in means over these dimensions determines the extent to which EU frontier firms differ significantly from non-frontier firms.

Table 1 reports these differences in average characteristics at aggregate level over the period 2003-2014. In addition, this table provides cross-sectional differences in average characteristics for 2 selected years: one year within the pre-recession period, 2006, and one in the recession period, 2013. Table 1 also shows these differences over the total period by three aggregate groups of industries: manufacturing, nonfinancial market services and other production. In all cases, the differences in means between frontier and non-frontier firms are based on the classification according to the TFP measure.

Over the period 2003-2014, firms at the EU frontier are on average 4.44 times more productive than non-frontier firms, indicating that the TFP gap between frontier and non-frontier-firms is sizeable and, therefore, suggesting that the potential for convergence in TFP remains enormous. ${ }^{9}$ In addition, EU frontier firms are on average older, larger, more capital intensive, have higher value added, profits, and pay higher wages per employee than non-frontier firms. These results are consistent with the findings in Andrews et al. (2016) for the global frontier firms with a sample

\footnotetext{
8 This is undertaken to avoid the possible variation across years in the number of firms representing the most productive $5 \%$ due to the unbalanced nature of the data.

9 Note that TFP is measured in logs, therefore, relative to non-frontier firms, frontier firms are on average $\exp (5.93-4.44)=4.44$ times more productive.
} 


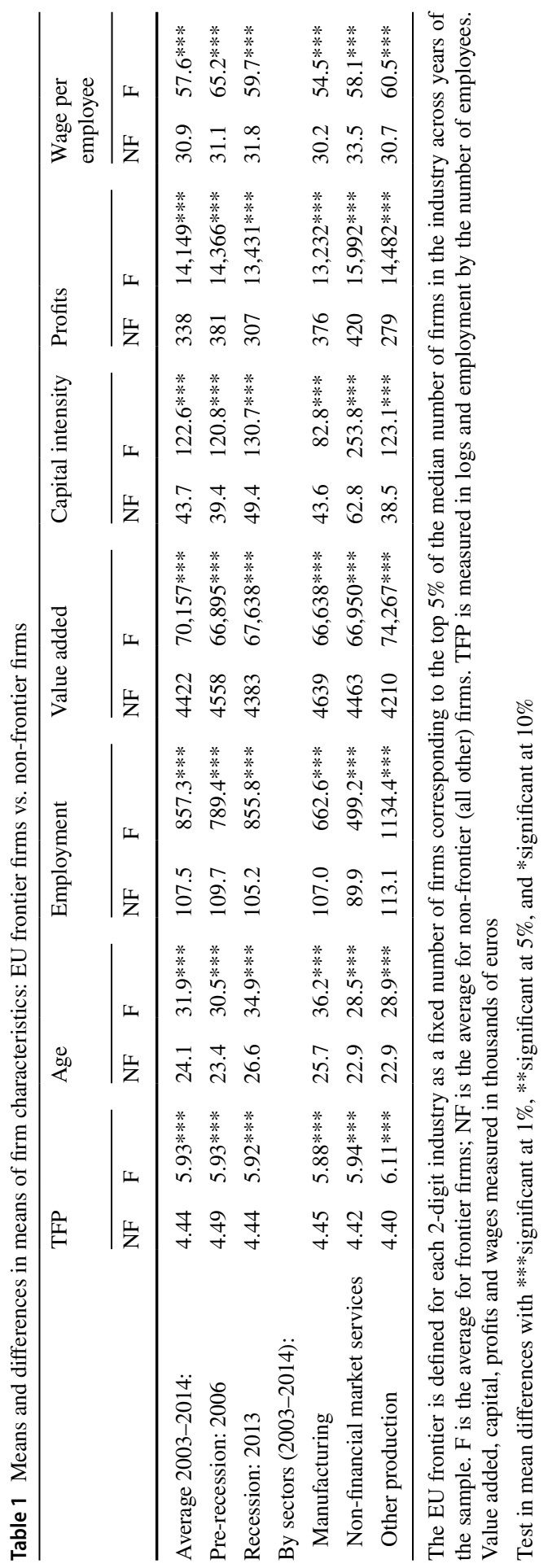


of 24 OECD countries. These features also hold when we look separately at those industries corresponding to manufacturing, non-financial market services and other production, respectively.

Comparing the reported statistics for 2006 (the pre-recession year) and 2013 (the recession year), we observe that there is a reduction in the average TFP both for nonfrontier and frontier firms. In addition, non-frontier firms experience a reduction in the average number of employees, value added, and profits, while capital intensity and average wage per employee increase. In contrast, frontier firms increase the average number of employees, value added and capital intensity, whereas average profits and wages per employee decrease.

\subsection{The EU frontier composition by country of origin}

The EU productivity frontier is comprised of firms from different countries, reflecting different patterns of comparative advantage and natural endowments within the EU. Table 2 shows the percentage of firms in the EU frontier by country of origin in the two selected years, 2006 and 2013. The figures presented in this table are computed following the two steps procedure described in Gal (2013). First, we calculate the percentage that the number of firms of country $c$ in year $t$ that belong to the EU frontier of industry $p$ represents over the total number of firms of country $c$ in year $t$ for that industry. Secondly, the average across industries of this percentage is calculated for each country. A value higher than 5\% means that the country has a relatively high percentage of firms at the frontier (that is, at the EU top 5\% of firms). For example, in 2013, on average across industries, $12.88 \%$ of firms in Germany are in the EU top 5\%. Countries in the table are ranked according to their 2013 values, from the best to the worst. The information is provided for the total number of industries and also separately for those industries corresponding to manufacturing, non-financial market services and other production. Notice that Gal (2013) methodology minimizes cross-country coverage differences in AMADEUS. These differences would have been exacerbated if participation of countries at the EU frontier would have been simply calculated as the percentage of firms at the frontier of each country of origin.

By looking at the country composition of the EU frontier in 2013 for the total of industries, we observe that those countries with higher participation (above 5\%) are Austria, the Netherlands, Belgium, Germany, Denmark, Ireland, and the UK, while firms in France, Sweden, Spain, Slovakia, Italy, and Hungary have lower participation in the top 5\% (from 3.29\% for Hungary to $4.69 \%$ for France). The remaining countries have clearly an even lower participation at the frontier, with the last three being Romania, Greece and Estonia. These country participation figures are in line with Gal (2013). ${ }^{10}$

\footnotetext{
${ }^{10}$ The paper by Gal (2013) provides these calculations for the year 2008 for 20 OECD countries from ORBIS database. This is a similar database to AMADEUS but for OECD countries. He also obtains that firms in EU countries such as the Netherlands, Belgium, Germany, Denmark and the UK show high participation in the OECD top 10\% firms, while firms in Spain, Italy and Portugal have lower participation. At the other end, Central-Eastern European countries and Greece are the ones with the lowest participation at the OECD frontier.
} 
By industry groups, the general results hold with few exceptions. In 2013, France belongs to the group of countries with high participation in the top 5\% in manufacturing, the same happens to Sweden and Slovakia for non-financial market services, and to Spain for other production. We also observe that from 2006 to 2013, the Netherlands achieves a noticeable increase in its participation among the EU frontier firms (from 10.48 to $16.76 \%$ ). However, there are also relevant decreases in frontier participation for countries such as Spain, Hungary, Italy and Greece. The increase for the Netherlands comes both from manufacturing and non-financial market services. The decreases for Spain, Italy and Greece affect the three groups of industries. In Hungary, the decline comes from manufacturing and non-financial market services.

\subsection{Evolution of TFP of EU frontier and non-frontier firms}

Before analyzing the factors explaining the distance of laggard firms to the technological frontier, we present in Table 3 the evolution of the average TFP of frontier and non-frontier firms. We observe that the average TFP gap between frontier and non-frontier firms is approximately equal to 4.44 during the sample period (with values ranging from the highest, 5.05 in 2003, to the lowest, 4.01 in 2014). This means that, on average across years, frontier firms are 4.44 times more productive than non-frontier firms. We observe, however, three different periods as regards the TFP gap. There is a decrease in the gap from 2003 until 2005. After this, we observe an increase in the gap that peaks in 2009. Finally, during the last years, 2009-2014, we notice a reduction in the gap.

\section{Determinants of the distance to the frontier}

We next analyze how our key institutional factors and other country and firms' characteristics may influence the distance of laggard firms to their technological frontier. As stated earlier, frontier firms are identified at the EU level (within each industry and year). We estimate a model with the distance to the frontier (or technology gap) on the left-hand side and our key regressors for institutional quality and controls both at the firm and country level on the right-hand side. In addition, we also include country, industry, firm and year fixed effects. Therefore, our estimating equation is as follows:

$$
\ln \frac{T F P_{i c p t}}{T F P_{p t}^{F}}=\alpha+\beta^{\prime} I F_{c t}+\delta^{\prime} X_{c t}+\varphi^{\prime} Z_{i c p t-1}+\gamma_{c}+\gamma_{p}+\gamma_{i}+\gamma_{t}+\varepsilon_{i c p t}
$$

where subscript $i$ denotes firm, subscript $c$ country, subscript $p$ corresponds to 2-digit industry and $t$ is the time period. The distance to the frontier of a particular laggard firm is calculated as the natural log of the ratio of its own TFP over the 
Table 2 Percentage of firms in the EU frontier by country of origin in selected years

\begin{tabular}{|c|c|c|c|c|c|c|c|c|}
\hline \multirow[b]{2}{*}{ Country } & \multicolumn{2}{|l|}{ Total } & \multicolumn{2}{|c|}{ Manufacturing } & \multicolumn{2}{|c|}{$\begin{array}{l}\text { Non-financial market } \\
\text { services }\end{array}$} & \multicolumn{2}{|c|}{ Other production } \\
\hline & 2006 & 2013 & 2006 & 2013 & 2006 & 2013 & 2006 & 2013 \\
\hline Austria & - & $22.82 \%$ & - & $29.73 \%$ & - & $18.86 \%$ & - & $12.50 \%$ \\
\hline Netherlands & $10.48 \%$ & $16.76 \%$ & $13.04 \%$ & $19.44 \%$ & $10.75 \%$ & $16.67 \%$ & - & - \\
\hline Belgium & $11.75 \%$ & $13.10 \%$ & $14.12 \%$ & $16.98 \%$ & $10.65 \%$ & $9.95 \%$ & $9.53 \%$ & $14.96 \%$ \\
\hline Germany & $14.01 \%$ & $12.88 \%$ & $16.28 \%$ & $14.89 \%$ & $13.84 \%$ & $12.53 \%$ & $8.67 \%$ & $8.36 \%$ \\
\hline Denmark & - & $12.60 \%$ & - & $11.37 \%$ & - & $12.23 \%$ & - & $17.65 \%$ \\
\hline Ireland & - & $9.89 \%$ & - & $15.00 \%$ & - & $7.46 \%$ & - & $25.00 \%$ \\
\hline UK & $9.27 \%$ & $9.55 \%$ & $8.40 \%$ & $7.23 \%$ & $9.14 \%$ & $10.53 \%$ & $13.51 \%$ & $12.92 \%$ \\
\hline France & $4.21 \%$ & $4.69 \%$ & $4.30 \%$ & $5.33 \%$ & $3.84 \%$ & $4.51 \%$ & $5.12 \%$ & $4.02 \%$ \\
\hline Sweden & $3.28 \%$ & $4.61 \%$ & $3.56 \%$ & $4.09 \%$ & $3.43 \%$ & $5.30 \%$ & $2.35 \%$ & $4.04 \%$ \\
\hline Spain & $9.92 \%$ & $3.64 \%$ & $10.18 \%$ & $3.48 \%$ & $8.87 \%$ & $3.11 \%$ & $15.28 \%$ & $7.86 \%$ \\
\hline Slovakia & $3.50 \%$ & $3.61 \%$ & $2.33 \%$ & $2.29 \%$ & $4.79 \%$ & $5.53 \%$ & $4.14 \%$ & $2.40 \%$ \\
\hline Italy & $5.01 \%$ & $3.57 \%$ & $4.99 \%$ & $4.16 \%$ & $5.03 \%$ & $2.83 \%$ & $5.05 \%$ & $3.00 \%$ \\
\hline Hungary & $5.35 \%$ & $3.29 \%$ & $5.70 \%$ & $2.95 \%$ & $5.74 \%$ & $3.67 \%$ & $2.94 \%$ & $2.89 \%$ \\
\hline Croatia & $1.71 \%$ & $2.52 \%$ & $1.44 \%$ & $2.41 \%$ & $2.38 \%$ & $3.23 \%$ & $0.98 \%$ & $1.06 \%$ \\
\hline Slovenia & $2.40 \%$ & $2.28 \%$ & $1.28 \%$ & $1.23 \%$ & $4.15 \%$ & $3.23 \%$ & $0.84 \%$ & $2.13 \%$ \\
\hline Czech Rep & $1.94 \%$ & $1.88 \%$ & $1.81 \%$ & $1.08 \%$ & $2.65 \%$ & $2.96 \%$ & $0.00 \%$ & $0.44 \%$ \\
\hline Poland & $1.92 \%$ & $1.87 \%$ & $1.34 \%$ & $1.99 \%$ & $2.70 \%$ & $1.79 \%$ & $0.89 \%$ & $1.83 \%$ \\
\hline Finland & $2.63 \%$ & $1.83 \%$ & $3.24 \%$ & $2.06 \%$ & $2.38 \%$ & $1.80 \%$ & $1.72 \%$ & $1.32 \%$ \\
\hline Portugal & - & $1.66 \%$ & - & $1.06 \%$ & - & $2.15 \%$ & - & $2.75 \%$ \\
\hline Bulgaria & $2.65 \%$ & $1.54 \%$ & $1.66 \%$ & $1.34 \%$ & $3.53 \%$ & $1.36 \%$ & $3.23 \%$ & $3.85 \%$ \\
\hline Romania & $0.59 \%$ & $0.89 \%$ & $0.43 \%$ & $0.65 \%$ & $0.84 \%$ & $1.34 \%$ & $0.81 \%$ & $0.93 \%$ \\
\hline Greece & $3.57 \%$ & $0.85 \%$ & $3.62 \%$ & $0.56 \%$ & $3.51 \%$ & $0.99 \%$ & $4.17 \%$ & $2.38 \%$ \\
\hline Estonia & $1.58 \%$ & $0.72 \%$ & $0.75 \%$ & $0.35 \%$ & $2.40 \%$ & $0.90 \%$ & $1.04 \%$ & $1.32 \%$ \\
\hline
\end{tabular}

1. Austria, Denmark, Ireland and Portugal have no coverage in AMADEUS for the year 2006 in the sample used for TFP measurement. The Netherlands has no coverage in AMADEUS for both years in the sample used for TFP measurement for the sector other production

2. Percentages are calculated in two steps. First, we calculate the percentage that the number of firms of country $c$ in year $t$ belonging to the EU frontier of industry $p$ represent over the total number of firms of country $c$ in year $t$ for that industry. Secondly, the average across industries of this percentage is calculated for each country. A value higher than $5 \%$ means that the country has a relatively high percentage of firms at the frontier (that is at the EU top 5\% of firms). Countries in the table are ranked according to their 2013 values, from the best to the worst

average TFP of the firms at the frontier for the same industry and year. ${ }^{11} I F_{c t}$ is a two dimensional vector including the two indicators of institutional quality at the country level. The first indicator, Country Governance Quality, is obtained following

\footnotetext{
11 According to the specification in (3) and the definition of the dependent variable, we are equivalently studying the determinants of the across time within-firm TFP variation in relation to the across time within-industry variation in the average TFP of frontier firms, that is, the across time within-firm TFP gap variation.
} 
Table 3 Evolution of TFP of EU frontier and non-frontier firms

\begin{tabular}{|c|c|c|c|c|c|c|c|}
\hline \multirow[t]{2}{*}{ Year } & \multicolumn{2}{|c|}{ All firms } & \multicolumn{2}{|c|}{$\begin{array}{l}\text { Frontier } \\
\text { firms }\end{array}$} & \multicolumn{2}{|c|}{$\begin{array}{l}\text { Non-frontier } \\
\text { firms }\end{array}$} & \multirow[t]{2}{*}{ TFP gap } \\
\hline & Mean & SD & Mean & SD & Mean & SD & \\
\hline 2003 & 4.50 & 0.66 & 6.04 & 0.27 & 4.42 & 0.60 & 5.05 \\
\hline 2004 & 4.53 & 0.67 & 6.02 & 0.25 & 4.44 & 0.61 & 4.85 \\
\hline 2005 & 4.55 & 0.68 & 5.86 & 0.28 & 4.45 & 0.61 & 4.10 \\
\hline 2006 & 4.57 & 0.67 & 5.93 & 0.28 & 4.49 & 0.61 & 4.22 \\
\hline 2007 & 4.58 & 0.66 & 5.95 & 0.27 & 4.50 & 0.59 & 4.26 \\
\hline 2008 & 4.53 & 0.65 & 5.92 & 0.27 & 4.45 & 0.58 & 4.35 \\
\hline 2009 & 4.44 & 0.68 & 5.89 & 0.28 & 4.36 & 0.62 & 4.62 \\
\hline 2010 & 4.54 & 0.64 & 5.94 & 0.28 & 4.46 & 0.58 & 4.39 \\
\hline 2011 & 4.53 & 0.64 & 5.93 & 0.28 & 4.46 & 0.57 & 4.35 \\
\hline 2012 & 4.51 & 0.66 & 5.92 & 0.26 & 4.43 & 0.60 & 4.44 \\
\hline 2013 & 4.53 & 0.66 & 5.92 & 0.26 & 4.44 & 0.60 & 4.39 \\
\hline 2014 & 4.52 & 0.67 & 5.81 & 0.28 & 4.42 & 0.59 & 4.01 \\
\hline $\begin{array}{c}\text { Average } \\
2003- \\
2014\end{array}$ & 4.53 & 0.66 & 5.93 & 0.27 & 4.44 & 0.60 & 4.44 \\
\hline
\end{tabular}

The EU frontier is defined for each 2-digit industry as a fixed number of firms that corresponds to the top $5 \%$ of the median number of firms in the industry across years of the sample. TFP is measured in logs. Values corresponding to 2014 should be taken with caution given the smaller number of observations in the sample. TFP gap is calculated as the difference in average TFP of frontier and non-frontier firms. Note that TFP is measured in logs, so that, for instance, the TFP gap in 2003 is $\exp (6.04-4.42)=5.05$, i.e., in 2003 frontier firms are on average 5.05 times more productive than non-frontier firms

Kaufmann et al. (2010) as a synthetic measure that relies on four indicators from the Worldwide Governance Indicators, namely, Government Effectiveness, Regulatory Quality, Rule of Law and Control of Corruption. ${ }^{12}$ Government effectiveness captures perceptions on the quality of public services, the quality of the civil service and the degree of its independence from political pressures, the quality of policy formulation and implementation, and the credibility of the government commitment to such policies. Regulatory Quality reflects the perceptions on the ability of the government to formulate and implement sound policies and regulations that allow and promote private sector development. Rule of Law captures the perceptions on the extent to which agents have confidence in and abide by the rules of society, and in particular the quality of contract enforcement, property rights, the police, and the

\footnotetext{
12 These indicators have been used in numerous studies, especially in the field of development studies. They have also been applied in a European context in studies such as Jankauskas and Seputiene (2007) and Kaasa (2016). The works of Lasagni et al. (2015) and Agostino et al. (2020), among others, use regional institutional synthetic indexes constructed following the structure of these country indicators.
} 
courts, as well as the likelihood of crime and violence. Finally, Control of Corruption captures perceptions on the extent to which public power is exercised for private gain, including both minor and grand forms of corruption, as well as "capture" of the state by elites and private interests (Chowdhury \& Audretsch, 2014). Given the high correlation among these four indicators and following a common practice in related literature, we apply factor analysis to obtain a synthetic measure, Country Governance Quality, which is a weighted sum of the original indicators, capturing the quality of the institutional governance in each country. We expect this variable to facilitate technological adoption and diffusion and so to contribute to reduce the technological gap among firms (Hypothesis 1).

The second variable measuring institutional quality is Country DTF Getting Credit, an indicator from the World Bank's dataset Doing Business capturing the distance regarding the easiness in getting credit between a particular country and the world best practice country. This indicator tries to capture both the strength of the credit system and the effectiveness of collateral and bankruptcy laws in facilitating lending. ${ }^{13}$ By construction, higher values of this indicator imply greater easiness in conducting business. According to Hypothesis 2, the effect of this variable in explaining the convergence of laggard firms to the technological frontier is a priori ambiguous.

As regards control variables at the country level, the vector $X_{c t}$ in (3) includes a set of variables capturing other macroeconomic context factors. First, as knowledge is expected to play a crucial role in explaining the distance of firms to the technological frontier, we include a measure of human capital, Country Tertiary Education, which is the percentage of 15-64 years old population with tertiary education, drawn from Eurostat. ${ }^{14}$ Secondly, we also include a knowledge-related variable such as the percentage of researchers in R\&D per million people (Country $R \& D$ stock) obtained from the World Bank Development Indicators. ${ }^{15}$ We expect these two variables to be related to the ability of the country to develop and absorb ideas and knowledge from the technological frontier and, therefore, to contribute to reduce the distance of laggards to the frontier. Finally, we include a measure of Country Trade Openness, calculated as the ratio of the sum of imports plus exports over GDP, obtained from the World Bank Development Indicators. The effect of trade openness on firms' productivity gap is a priori ambiguous. On the one hand, exposure to trade is an important driver contributing to a better resource allocation, by selecting the most productive firms into the export markets and inducing the less efficient firms to exit, thereby affecting within-industry productivity dispersion (Amiti \& Konings, 2007;

\footnotetext{
13 In particular, this indicator measures two types of institutions and systems that may facilitate access to finance and improve its allocation: (i) Legal rights of borrowers and lenders in secured transactions and bankruptcy laws; and, (ii) Coverage, scope and quality of credit information available through credit registries and bureaus.

14 The importance of terciary education on labor productivity has been documented in a number of studies, such as Børing (2019).

15 We use a measure of R\&D stock at the country level, since we do not have information on R\&D at the firm level. The importance of corporate R\&D on labor productivity has been widely documented (see, among others, Kumbhakar et al., 2012; Castellani et al., 2019).
} 
Fernandes, 2007; Melitz, 2003). In that case, we expect trade openness to be associated with a reduction of the distance of laggards to the technological frontier. On the other hand, trade openness may also affect firms' productivity and within-industry reallocation through other channels, such as changing firms' incentives to innovate (see Shu \& Steinwender, 2018, and references therein). Since import competition in domestic product markets affects competitive pressure, it may either encourage or discourage firms' innovation incentives and, hence, affect productivity dispersion (Beneito et al., 2014, 2015, 2017). ${ }^{16}$

Finally, the vector $Z_{i c p t-1}$ in (3) accounts for variables at the firm-level, such as firms' size, age, and capital intensity, that have been found to affect productivity at the firm level (see, for instance, Syverson, 2011; Børing, 2019). The $\gamma$ 's in (3) are country, industry, firm and year fixed effects, respectively, and $\varepsilon_{i c p t}$ is a standard i.i.d. error term. In Table 4, we report the descriptive statistics of all regressors in (3). Furthermore, in Table 9 in the Appendix we present the Pearson correlation matrix for the variables used in our analysis. In the final row of the table, we show the variance inflation factors (VIFs) for each of the explanatory variables. Since all VIFs are smaller than 6.18 , this indicates that we have no serious multicollinearity problems (Chatterjee et al., 2000). The VIF values range from 1.01 for firm's size to 6.18 for the country-level governance quality index.

\subsection{The effects of the key institutional regressors}

The estimation results obtained by linear regression are presented in Table 5. All regressions are run only with non-frontier firm distances. Results were similar when also including frontier firms, in which case the corresponding log value for the dependent variable for frontier-firms was set to zero. Coefficient estimates for the regressors at the firm-level have the interpretation of elasticities since both the dependent variable and firm level regressors are in log form. The proper interpretation of the sign of estimated coefficients from Eq. (3) is the following: a positive coefficient for a given regressor means that it contributes to reduce the distance to the EU frontier; and, a negative one the opposite. Notice that in Eq. (3) the dependent variable is defined as $\ln \left(\frac{T F P_{i c p t}}{T F P_{p t}^{F}}\right)=\ln T F P_{i c p t}-\ln T F P_{p t}^{F}$.

In Column (1) of Table 5 we present the estimation of Eq. (3) above. As regards to our key regressors for institutional quality, we find that governance quality significantly and positively contributes to reduce the technological distance of laggards to the frontier, providing support to Hypothesis 1 . This result is in line with existing literature. For instance, Arnold et al. (2008) and Andrews et al. (2015) document

\footnotetext{
${ }^{16}$ Results on the effects of competition on firms' incentives to innovate are mixed. Beneito et al. (2014) find that the effect of competition on innovation varies with the type of innovation. In addition, Beneito et al. (2015) show that it also depends on the origin of the competition changes, and that efficient and inefficient firms may respond to these changes differently. Further, Beneito et al. (2017) extend the model of Aghion et al. (2005) to show that in industries with high competitive pressure, enhanced competition may reduce the within-industry technological gap, not only because laggard firms may have incentives to innovate to avoid exit, but also because increased competition may induce the exit of inefficient firms.
} 
how product market regulations that restrain competitive pressure negatively affect firms' productivity, implying that a weak market and institutional framework may impose a burden on firms' productivity growth. However, regarding Hypothesis 2, results in Column (1) indicate that the effect of the easiness in getting credit is negative for convergence (as expected if there is misallocation of capital) but statistically non-significant.

To test for Hypotheses 3 and 4, which are related to the moderating effect of the Great Recession on the effects of institutional quality on firms' TFP convergence to the frontier, in Column (2) we include the same regressors as in Column (1), but we also interact the regressors with a dummy variable taking value 1 for recession years, 2008-2014. Hence, the estimates for non-interacted regressors in this column correspond to the reference category, pre-recession years, 2003-2007. In order to interpret the result for the recession years, the coefficients of the interacted regressors should be added to the corresponding coefficients of the reference category (pre-recession).

As shown in Column (2), we obtain that the positive impact of governance quality on TFP convergence is similar in the recession period than in the pre-recession period, whereas the effect of the easiness in getting credit is negative and statistically significant only in the pre-recession period (in the recession years it is statistically non-significant). ${ }^{17}$ From this cross-products regression in Column (2), we can only provide evidence supporting Hypothesis 4, which works in the direction of the existence of capital misallocation in Europe's pre-crisis period (a period of excessive and sometimes indiscriminate credit provision). Capital was probably allocated to less productive firms allowing their survival and, thereby, contributing to increase the distance of laggards to the EU frontier. Differently, higher discipline in credit provision during the Great Recession could have offset the previous period misallocation of capital by diverting funds towards more productive firms.

We next control for the intertemporal shift of the TFP frontier. By conditioning on the frontier TFP growth, we are able to identify more precisely the factors contributing to reduce the distance of laggards to their industrial frontier. This is done in Columns (3) and (4) of Table 5, which extend Columns (1) and (2), respectively. In particular, we estimate Eq. (3) with an additional control measuring the TFP growth (from period $t-2$ to $t-1$ ) of the industry frontier. Our estimating equation in this case is as follows:

$$
\begin{aligned}
& \ln \frac{T F P_{i c p t}}{T F P_{p t}^{F}}=\alpha+\beta^{\prime} I F_{c t}+\delta^{\prime} X_{c t}+\varphi^{\prime} Z_{i c p t-1} \\
& +\theta\left(\ln T F P_{p t-1}^{F}-\ln T F P_{p t-2}^{F}\right) \\
& +\gamma_{c}+\gamma_{p}+\gamma_{i}+\gamma_{t}+\varepsilon_{i c p t}
\end{aligned}
$$

\footnotetext{
17 Since for recession years we should add the coefficient of the interacted regressor to the coefficient corresponding to the reference category, pre-recession, this cancels out the effect of the variable easiness in getting credit during the recession period.
} 
Table 4 Descriptive statistics of the determinants of the distance to the frontier

\begin{tabular}{lrr}
\hline & \multicolumn{1}{c}{ Mean } & \multicolumn{1}{c}{ SD } \\
\hline Firm Size (number of employees) & 111.590 & 390.638 \\
Firm Age & 24.456 & 18.371 \\
Firm Capital Intensity (thousand €/employees) & 45.037 & 104.633 \\
Country Tertiary Education (\%) & 20.852 & 7.103 \\
Country R\&D Stock (\%) & 0.298 & 0.128 \\
Country Trade Openness (\%) & 72.473 & 30.444 \\
Country DTF Getting Credit & 64.129 & 16.733 \\
Country Governance Quality & -0.044 & 0.837 \\
\hline
\end{tabular}

Country DTF Getting Credit scores are on a scale from 0 to 100 , where 0 represents the worst performance and 100 represents the best performance. The individual components from the Worldwide Governance Indicators behind the synthetic index Country Governance Quality run from approximately -2.5 to 2.5 , with higher values corresponding to better governance

where $\operatorname{lnTFP} P_{p t-1}^{F}-\ln T F P_{p t-2}^{F}$ is the rate of growth of the average TFP of frontier firms in industry $p$ from period $t-2$ to $t-1$. Importantly, the estimate for parameter $\theta$ will inform on whether the growth rate of the technological frontier contributes to reduce the distance of laggards to the technological frontier. If this is the case, this may suggest that there are positive knowledge spillovers from frontier to nonfrontier firms within an industry and, hence, that laggard firms benefit from them.

The only remarkable difference between Column (3) and Column (1) results is that when we control for the productivity improvement of the frontier, the coefficient of easiness in getting credit remains negative but becomes statistically significant, which is consistent with capital misallocation for the whole analyzed period. However, our preferred estimates are those in Column (4), since they both control for the intertemporal shift of the frontier and allow for heterogeneous effects of regressors during the recession period compared to the pre-recession years. These results show that during the recession period governance quality further reinforces its contribution to reduce the technological gap, providing support to Hypothesis 3. The coefficient for easiness in getting credit is negative and statistically significant, although its magnitude is considerably reduced during the recession period compared to the previous period. Hence, these findings provide support to Hypothesis 4, indicating that easiness in getting credit contributes to increase the technological gap, suggesting capital misallocation, especially during the pre-recession years. This effect is considerably softened during the recession period.

Finally, in Column (3) we also observe that the TFP growth of the frontier contributes to increase the technological gap between laggards and frontier firms during the whole period analyzed. Furthermore, when we consider the Great Recession we observe in Column (4) that the effect of the TFP growth of the frontier in increasing the technological gap is much stronger during the 


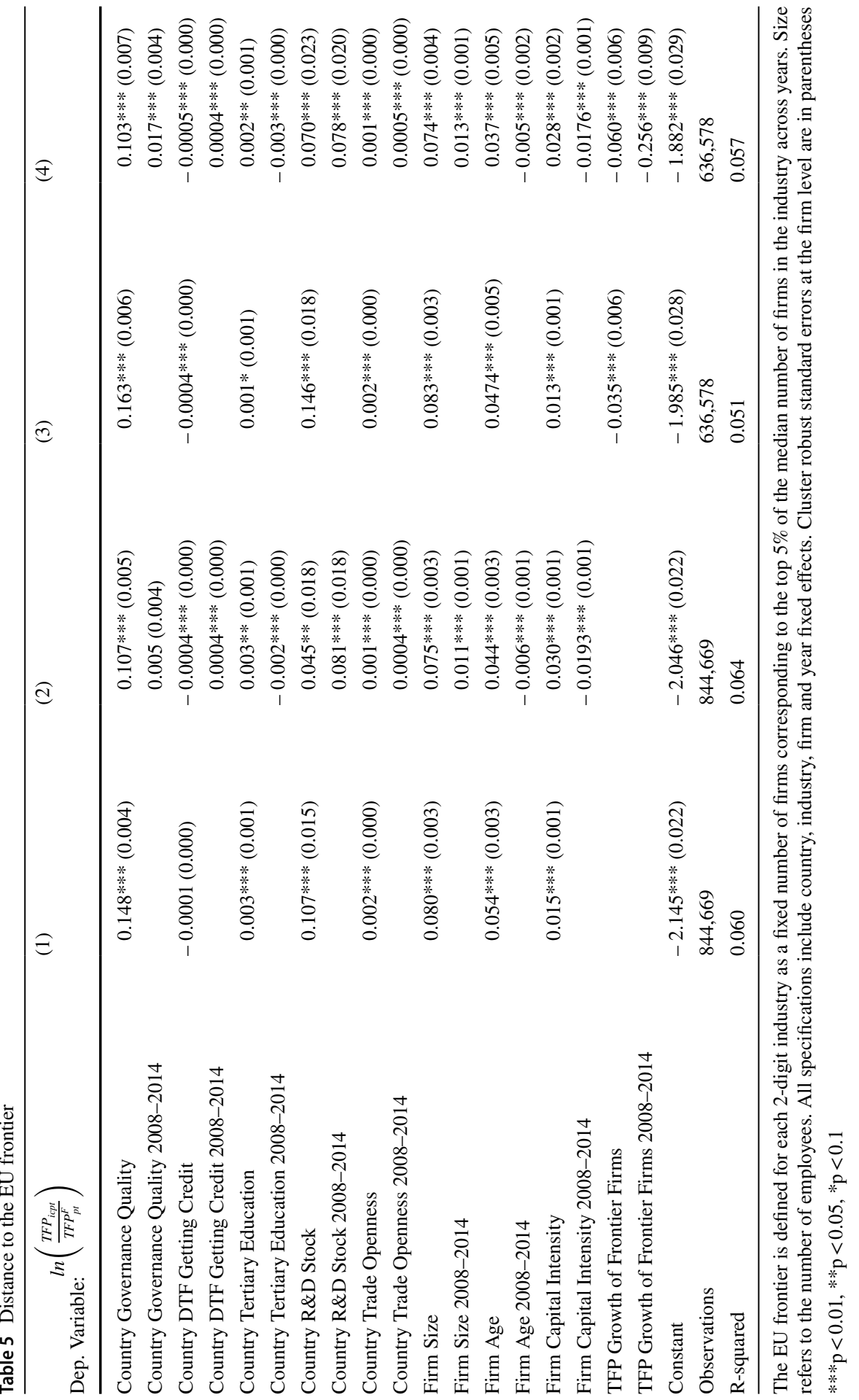


recession period. This suggests that laggard firms could not benefit from positive technological spillovers from advances in their frontier, and that the ability to learn from and imitate technological leaders becomes more difficult during the recession period.

\subsection{The effects of the control variables}

Regarding the effects of control variables at the country-level, we obtain that tertiary education, $R \& D$ stock and trade openness significantly and positively contribute to lower the distance of laggards to the frontier, results that are consistent with existing studies such as Añón-Higón et al. (2018), who, from a macroeconomic perspective, obtain a positive impact of R\&D in fostering countries' TFP growth in a study on productivity convergence across EU countries, and Iacovone and Crespi (2010), who provide evidence on the role of trade openness in firms' productivity convergence. In addition, the effect of reducing the distance to the frontier becomes weaker during the Great Recession for tertiary education, but stronger for R\&D stock and trade openness. ${ }^{18}$ We would like to highlight the weaker contribution of tertiary education to closing the productivity gap to the frontier during the recession period. Skill-based technological change, globalization and offshoring have changed skills demand in the EU, placing universities at the center of the debate about their ability to adapt and provide required skills beyond university diplomas (Hoftijzer \& Gortazar, 2018). Calero et al. (2016) reveal that tertiary education for the cohorts born between 1960 and 1975 was associated with better skills than the previous cohorts, and also better skills than the cohorts born from 1980 to 1990. In addition, it could also be the case that labor skills have depreciated in the EU during the Great Recession because of high unemployment rates and more temporary contracts, with a reduction in on-the-job training (Cabrales et al., 2014).

For firm-level control variables, we find that size, age, and capital intensity contribute significantly to reduce the distance to the frontier. ${ }^{19}$ For instance, according to results in Column (1) in Table 5, a one per cent increase in size (as measured by the number of employees) reduces the distance to the frontier by 0.080 per cent, a one per cent increase in age reduces the distance to the frontier by 0.054 per cent, and a one per cent increase in capital intensity reduces the distance to the frontier by 0.015 per cent.$^{20}$ Furthermore, results indicate that size decreases the distance to the frontier more in the recession than in the pre-recession period. Differently, age and capital intensity narrow the gap less in the recession than in pre-recession years.

\footnotetext{
18 In Column (4) of Table 5, where we control for the intertemporal shift of the frontier, the positive role of tertiary education in reducing the technological gap becomes slightly negative during the recession period.

19 Differently to Andrews et al. (2015) for OECD countries and to Conway et al. (2015) for New Zealand, we do not find that frontier firms are more likely to be younger than laggard firms.

${ }^{20}$ Kumbhakar et al. (2012) analyze a sample of 532 top EU R\&D investors over the period 2000-2005 using stochastic frontier techniques and find that physical capital increases labor productivity. They argue that this finding suggests that "embodied technological change" is crucial to operate "closer" to the frontier.
} 


\section{Concluding remarks}

This study provides novel evidence on the institutional factors contributing to reduce the distance of laggard firms to the European frontiers. By doing so, we focus on two central questions: (1) Do key institutional factors at the country level, such as governance quality and the easiness in getting credit, contribute (and how) to the convergence of laggard firms in the EU to their EU technological leaders? (2) Have the effects of these institutional factors been different during the Great Recession as compared to pre-recession years? As regards to the first question, we find that governance quality positively contributes to the convergence process of laggards to the technological frontier. Additionally, regarding the easiness in getting credit, we find evidence supporting capital misallocation to less productive firms, which may have contributed to their survival and, hence, to the increase of the within industry productivity gap between laggards and leaders. As for the second question, we show that while the contribution of governance quality to reduce the distance of laggards to the frontier is reinforced during the recession period, the problem of capital misallocation in the pre-recession years is softened during the Great Recession. It seems that during the pre-recession period there was an excess of financial resources or an exceedingly easy access to credit for firms in the EU. This misallocation process was alleviated during the recession, a period characterized by tighter credit provision that most likely reallocated capital to more productive firms.

Beyond our key institutional factors, our study also shows that other country characteristics such as tertiary education, R\&D stock and trade openness are relevant factors in explaining the convergence of laggard firms to the frontier. In addition, firm level characteristics such as size, age and capital intensity also contribute to closing the gap to the technological frontier. The Great Recession strengthens the importance of R\&D stock and trade openness at the country level and the size of the firm in the process of convergence to the frontier. Finally, it appears that laggard firms in Europe have obstacles in benefiting from technological spillovers from the frontier, and that this has been exacerbated during the Great Recession.

Our findings suggest a number of implications, both for managers and policy makers. First, it seems advisable for managers to pursue strategies aimed at strengthening firms' characteristics such as size and capital intensity. Secondly, the importance of institutional factors at the country level suggests that there is room for policy measures to reduce the technological gap between laggards and frontier firms. In particular, improving the quality of governance seems to be a relevant institutional factor contributing to reduce the technological gap, especially during the downturn period. In addition, the need for policies aimed at better capital allocation to more efficient firms has become evident. This points towards the necessity to reduce informational asymmetries between lenders and borrowers, to a better evaluation of risks by the banking sector and, probably, to a tighter control over financial institutions. Finally, investments in human capital for new and better skills, the promotion of trade openness and R\&D stock of knowledge, and the facilitation of absorbing advanced technologies may serve to increase aggregate productivity by reducing the distance of laggards to the technological frontier. 
Although this study provides relevant insights, it is not without limitations that future research should address. First, not all countries in our sample receive the same coverage in the AMADEUS database. Nonetheless, we have made efforts in line with Arnold et al. (2008), Gal (2013), and Andrews et al. (2015) to ensure representativeness of the final sample. Second, the availability of more variables capturing firms' characteristics can contribute to a better fit of the model and a more accurate estimate of the role that institutional factors have in the convergence of laggard firms to their technological frontiers. Therefore, it is a challenge for future research in this area to have richer firm-level panel surveys covering EU countries in a comparable manner.

\section{Appendix 1. Productivity estimation and some descriptives}

We assume that firms produce using a Cobb-Douglas technology:

$$
y_{i c p t}=\beta_{0 p}+\beta_{L p} l_{i c p t}+\beta_{K p} k_{i c p t}+\omega_{i c p t}+\eta_{i c p t}
$$

where $i$ denotes firm, $c$ refers to country, $p$ denotes the 2-digit industry and $t$ is the time period. $y_{i c p t}$ is the natural $\log$ of value added of firm $i$ at time $t, l_{i c p t}$ is the natural $\log$ of labor, and $k_{i c p t}$ is the log of capital. As for the unobservables, $\omega_{i c p t}$ is total factor productivity (not observed by the econometrician but observable or predictable by the firm) and $\eta_{i c p t}$ is a standard i.i.d. error term that is neither observable nor predictable by the firm. Under the assumption that capital is a state variable, whereas labor can be adjusted when firms face a productivity shock (i.e., it is a variable factor), ${ }^{21}$ Olley and Pakes (1996) show how to obtain consistent estimates of the production function using a semiparametric procedure (see Levinsohn \& Petrin, 2003, for a closely related estimation strategy). In this paper, we follow Wooldridge (2009) that argues that both Olley and Pakes (1996) and Levinsohn and Petrin (2003) procedures can be reconsidered as consisting of two equations that can be jointly estimated by GMM, using the appropriate instruments. The first equation deals with the problem of endogeneity of labor. The second equation tackles the issue of the law of motion of productivity.

To solve the problem of endogeneity of labor, we follow Levinsohn and Petrin (2003) and use the demand of materials to proxy for "unobserved" productivity. This demand of materials function, $m_{\text {icpt }}(\cdot)$, is assumed to have a unique unobservable among its arguments (scalar unobservable assumption) and to be strictly monotonic on unobserved productivity. Thus, given that in equilibrium the demand of materials only depends on state variables, we can write this demand as $m_{\text {icpt }}=m_{t}\left(k_{\text {icpt }}, \omega_{\text {icpt }}\right)$. Under the scalar unobservable and the monotonicity assumptions, the demand of materials can be inverted to generate, $\omega_{i c p t}=m_{t}^{-1}\left(k_{i c p t}, m_{i c p t}\right)=h_{t}\left(k_{i c t p}, m_{i c t p}\right)$,

\footnotetext{
21 The law of motion of capital follows a dynamic process according to which $K_{\text {icpt }}=(1-\delta) K_{\text {icpt-1 }}+I_{\text {icpt-1 }}$. Thus, it is assumed that the capital a firm uses in period $t$ was actually decided in period $t-1$. Labor and materials (unlike capital) are chosen in period $t$, the period they actually get used and, therefore, they can be considered as function of $\omega_{\text {icpt }}$.
} 
where $h_{t}$ is an unknown function in its arguments. Then, substituting into the production function (5) we get our first estimation equation.

$$
y_{i c p t}=\beta_{0 p}+\beta_{L p} l_{i c p t}+\beta_{K p} k_{i c p t}+h_{t}\left(k_{i c p t}, m_{i c p t}\right)+\eta_{i c p t}
$$

Since $h_{t}(\cdot)$ is proxied by a third degree polynomial in its arguments and includes a constant term, $\beta_{0 p}$ and $\beta_{K p}$ are not identified from Eq. (6). This is achieved by the inclusion of a second equation in the GMM system that deals with the law of motion of productivity:

$$
\omega_{i c p t}=E\left[\omega_{i c p t} \mid \omega_{i c p t-1}\right]+\xi_{i c p t}=f\left(\omega_{i c p t-1}\right)+\xi_{i c p t}
$$

where $f(\cdot)$ is a function that relates productivity in $t$ to productivity in $t-1$, and $\xi_{\text {ictp }}$ is an innovation term uncorrelated by definition with $k_{\text {icpt }}$.

Using that $\omega_{\text {icpt }}=h_{t}\left(k_{\text {icpt }}, m_{\text {icpt }}\right)$, we can rewrite Eq. (7) as

$$
\omega_{i c p t}=f\left(\omega_{i c p t-1}\right)+\xi_{i t}=f\left(h_{t-1}\left(k_{i c p t-1}, m_{i c p t-1}\right)\right)+\xi_{i c p t}=g_{t}\left(k_{i c p t-1}, m_{i c p t-1}\right)+\xi_{i c p t}
$$

Finally, plugging Eq. (8) in the production function (5), we get our second estimation equation:

$$
y_{i c p t}=\beta_{0 p}+\beta_{L p} l_{i c p t}+\beta_{K p} k_{i c p t}+g_{t}\left(k_{i c p t-1}, m_{i c p t-1}\right)+u_{i c p t}
$$

where $g_{t}(\cdot)$ is an unknown function proxied by a third degree polynomial in its arguments and $u_{i c p t}=\xi_{i c p t}+\eta_{i c p t}$ is a composed error term.

Wooldridge (2009) proposes to estimate jointly (6) and (9) by GMM, using the appropriate instruments for each equation. This joint estimation strategy has the advantages of increasing efficiency relatively to two-step procedures and making unnecessary bootstrapping for the calculus of standard errors. ${ }^{22}$ Using this method, we obtain, for each of the 26 industries considered, both the coefficient estimates of the production function and firms' productivity as the following residual:

$$
\widehat{\omega}_{i c p t}=y_{i c p t}-\widehat{\beta}_{L p} l_{i c p t}-\widehat{\beta}_{K p} k_{i c p t}
$$

The production function in (5) is estimated separately for each of the two-digit industries but pooled across all countries and years, controlling for country and year fixed effects. This allows for technological differences across industries, while simultaneously facilitating both international and over time comparability of the resulting productivity levels. The industry classification is displayed in Table 6 . The estimated industry-specific input elasticities and the firms' mean productivity (TFP) are shown in Table 7.

22 Authors have programed the estimation method in STATA. 
Table 6 Industry classification

\begin{tabular}{lll}
\hline Code & Code NACE-Rev2 & Industry description \\
\hline 1 & & Manufacturing \\
2 & C10-C12 & Manuf. of food, beverages and tobacco \\
3 & C13-C15 & Manuf. of textiles, wearing apparel, leather \\
4 & C16-C18 & Manuf. of wood, paper, printing \\
5 & C19 & Manuf. of coke and refined petroleum prod \\
6 & C20 & Manuf. of chemicals and chemical prod \\
7 & C21 & Manuf. of pharmaceutical products \\
8 & C22-C23 & Manuf. of rubber, plastic and non-metallic \\
9 & C24-C25 & Manuf. of basic and fabricated metal prod \\
10 & C26 & Manuf. of computer, electronic and optical \\
11 & C27 & Manuf. of electrical equipment \\
12 & C28 & Manuf. of machinery and equipment n.e.c \\
13 & C29-C30 & Manuf. of motor vehicles, trailers \\
& C31-C33 & Manuf. of furniture; jewellery, musical prod \\
14 & & Non-financial market services \\
15 & G45 & Wholesale and retail trade of motor vehicles \\
16 & G46 & Wholesale trade, except of motor vehicles \\
17 & G47 & Retail trade, except of motor vehicles \\
18 & H49-H52 & Transport and storage \\
19 & H53 & Postal and courier activities \\
20 & I & Jccommodation and food service activities \\
21 & J68-J60 & Publishing, motion picture, video, television \\
22 & J62-J63 & Telecommunications \\
24 & F & Computer programing, consultancy \\
25 & & Professional, scientific and technic. activities \\
& Other production \\
\hline & Electricity, gas, steam and air cond. supply \\
& & Water suppl.; sewerage, waste management \\
& & Construction \\
\hline
\end{tabular}

Industry classification based on NACE Rev. 2, limited to the market non-farm/agricultural non-financial sectors (that is, excluding industries $\mathrm{A}, \mathrm{B}$, and $\mathrm{O}$ to $\mathrm{P}$ ) 
Table 7 TFP estimation by industry

\begin{tabular}{|c|c|c|c|c|c|c|c|c|}
\hline CODE & $\begin{array}{l}\text { NACE } \\
\text { Rev. } 2\end{array}$ & $\beta_{1}$ (s.e.) & $\beta_{\mathrm{k}}($ s.e. $)$ & Mean TFP & Firms & $\%$ & Observations & $\%$ \\
\hline 1 & $\mathrm{C} 10-\mathrm{C} 12$ & $\begin{array}{l}0.594 * * * \\
(0.002)\end{array}$ & $\begin{array}{l}0.107 * * * \\
(0.006)\end{array}$ & 4.451 & 11,125 & 5.36 & 68,217 & 6.07 \\
\hline 2 & C13-C15 & $\begin{array}{l}0.754 * * * \\
(0.002)\end{array}$ & $\begin{array}{l}0.083 * * * \\
(0.005)\end{array}$ & 3.727 & 8035 & 3.87 & 44,455 & 3.96 \\
\hline 3 & C16-C18 & $\begin{array}{l}0.673 * * * \\
(0.003)\end{array}$ & $\begin{array}{l}0.073 * * * \\
(0.006)\end{array}$ & 4.384 & 7790 & 3.75 & 46,771 & 4.16 \\
\hline 4 & C19 & $\begin{array}{l}0.535 * * * \\
(0.031)\end{array}$ & $\begin{array}{l}0.172 * * * \\
(0.060)\end{array}$ & 5.107 & 144 & 0.07 & 784 & 0.07 \\
\hline 5 & $\mathrm{C} 20$ & $\begin{array}{l}0.629 * * * \\
(0.004)\end{array}$ & $\begin{array}{l}0.095 * * * \\
(0.013)\end{array}$ & 4.921 & 3145 & 1.51 & 20,164 & 1.79 \\
\hline 6 & $\mathrm{C} 21$ & $\begin{array}{l}0.652 * * * \\
(0.009)\end{array}$ & $\begin{array}{l}0.080 * * * \\
(0.024)\end{array}$ & 5.217 & 843 & 0.41 & 5174 & 0.46 \\
\hline 7 & $\mathrm{C} 22-\mathrm{C} 23$ & $\begin{array}{l}0.624 * * * \\
(0.002)\end{array}$ & $\begin{array}{l}0.121 * * * \\
(0.006)\end{array}$ & 4.382 & 9,688 & 4.66 & 59,074 & 5.26 \\
\hline 8 & $\mathrm{C} 24-\mathrm{C} 25$ & $\begin{array}{l}0.717 * * * \\
(0.002)\end{array}$ & $\begin{array}{l}0.106^{* * * *} \\
(0.004)\end{array}$ & 4.141 & 15,323 & 7.38 & 90,006 & 8.01 \\
\hline 9 & $\mathrm{C} 26$ & $\begin{array}{l}0.653 * * * \\
(0.005)\end{array}$ & $\begin{array}{l}0.094 * * * \\
(0.093)\end{array}$ & 4.670 & 2279 & 1.10 & 12,508 & 1.11 \\
\hline 10 & $\mathrm{C} 27$ & $\begin{array}{l}0.633 * * * \\
(0.004)\end{array}$ & $\begin{array}{l}0.107 * * * \\
(0.010)\end{array}$ & 4.594 & 3051 & 1.47 & 18,380 & 1.64 \\
\hline 11 & C28 & $\begin{array}{l}0.681 * * * \\
(0.003)\end{array}$ & $\begin{array}{l}0.083 * * * \\
(0.005)\end{array}$ & 4.617 & 7378 & 3.55 & 42,996 & 3.83 \\
\hline 12 & C29-C30 & $\begin{array}{l}0.666^{* * * *} \\
(0.004)\end{array}$ & $\begin{array}{l}0.102 * * * \\
(0.010)\end{array}$ & 4.546 & 2994 & 1.44 & 18,078 & 1.61 \\
\hline 13 & C31-C33 & $\begin{array}{l}0.740 * * * \\
(0.003)\end{array}$ & $\begin{array}{l}0.087 * * * \\
(0.006)\end{array}$ & 4.053 & 7820 & 3.77 & 44,089 & 3.92 \\
\hline 14 & G45 & $\begin{array}{l}0.703 * * * \\
(0.003)\end{array}$ & $\begin{array}{l}0.050 * * * \\
(0.005)\end{array}$ & 4.585 & 8706 & 4.19 & 52,769 & 4.70 \\
\hline 15 & G46 & $\begin{array}{l}0.651 * * * \\
(0.001)\end{array}$ & $\begin{array}{l}0.036 * * * \\
(0.004)\end{array}$ & 5.014 & 26,032 & 12.53 & 145,990 & 13.00 \\
\hline 16 & G47 & $\begin{array}{l}0.648^{*} * * \\
(0.002)\end{array}$ & $\begin{array}{l}0.056 * * * \\
(0.005)\end{array}$ & 4.434 & 15,432 & 7.43 & 79,423 & 7.07 \\
\hline 17 & H49-H52 & $\begin{array}{l}0.753 * * * \\
(0.002)\end{array}$ & $\begin{array}{l}0.076 * * * \\
(0.005)\end{array}$ & 4.206 & 11,984 & 5.77 & 62,278 & 5.54 \\
\hline 18 & H53 & $\begin{array}{l}0.724 * * * \\
(0.021)\end{array}$ & $\begin{array}{l}0.080 * * * \\
(0.036)\end{array}$ & 4.170 & 221 & 0.11 & 904 & 0.08 \\
\hline 19 & I & $\begin{array}{l}0.676^{* * *} * \\
(0.003)\end{array}$ & $\begin{array}{l}0.056 * * * \\
(0.005)\end{array}$ & 4.233 & 12,766 & 6.15 & 63,917 & 5.69 \\
\hline 20 & J58-J60 & $\begin{array}{l}0.797 * * * \\
(0.007)\end{array}$ & $\begin{array}{l}0.043 * * * \\
(0.014)\end{array}$ & 4.509 & 2239 & 1.08 & 10,232 & 0.91 \\
\hline 21 & J61 & $\begin{array}{l}0.650 * * * \\
(0.010)\end{array}$ & $0.042 *(0.024$ & 5.136 & 649 & 0.31 & 2767 & 0.25 \\
\hline 22 & J62-J63 & $\begin{array}{l}0.897 * * * \\
(0.003)\end{array}$ & $\begin{array}{l}0.037 * * * \\
(0.008)\end{array}$ & 4.159 & 3384 & 1.63 & 13,591 & 1.21 \\
\hline 23 & M_N & $\begin{array}{l}0.700 * * * \\
(0.001)\end{array}$ & $\begin{array}{l}0.050^{* * * *} \\
(0.004)\end{array}$ & 4.575 & 18,196 & 8.76 & 76,483 & 6.81 \\
\hline
\end{tabular}


Table 7 (continued)

\begin{tabular}{|c|c|c|c|c|c|c|c|c|}
\hline CODE & $\begin{array}{l}\text { NACE } \\
\text { Rev. } 2\end{array}$ & $\beta_{1}$ (s.e.) & $\beta_{\mathrm{k}}$ (s.e.) & Mean TFP & Firms & $\%$ & Observations & $\%$ \\
\hline 24 & $\mathrm{D}$ & $\begin{array}{l}0.482 * * * \\
(0.006)\end{array}$ & $\begin{array}{l}0.124 * * * \\
(0.024)\end{array}$ & 5.432 & 1416 & 0.68 & 8204 & 0.73 \\
\hline 25 & $\mathrm{E}$ & $\begin{array}{l}0.695 * * * \\
(0.003)\end{array}$ & $\begin{array}{l}0.110^{* * * *} \\
(0.009)\end{array}$ & 4.249 & 3270 & 1.57 & 18,702 & 1.66 \\
\hline 26 & $\mathrm{~F}$ & $\begin{array}{l}0.736 * * * \\
(0.002)\end{array}$ & $\begin{array}{l}0.092 * * * \\
(0.003)\end{array}$ & 4.179 & 23,779 & 11.45 & 117,404 & 10.45 \\
\hline
\end{tabular}

The total number of observations is $1,123,360$, corresponding to 207,689 firms

Table 8 Distribution of firms and observations across countries

\begin{tabular}{|c|c|c|c|c|}
\hline & Firms & $\%$ & Observations & $\%$ \\
\hline Austria & 466 & 0.22 & 1315 & 0.12 \\
\hline Belgium & 5121 & 2.47 & 38,538 & 3.43 \\
\hline Bulgaria & 1829 & 0.88 & 9195 & 0.82 \\
\hline Czech Rep & 7294 & 3.51 & 42,872 & 3.82 \\
\hline Germany & 14,864 & 7.16 & 64,465 & 5.74 \\
\hline Denmark & 1447 & 0.70 & 4084 & 0.36 \\
\hline Estonia & 1092 & 0.53 & 7759 & 0.69 \\
\hline Spain & 30,640 & 14.75 & 175,877 & 15.66 \\
\hline Finland & 3807 & 1.83 & 20,089 & 1.79 \\
\hline France & 39,075 & 18.81 & 206,782 & 18.41 \\
\hline UK & 15,255 & 7.35 & 88,823 & 7.91 \\
\hline Greece & 3749 & 1.81 & 21,650 & 1.93 \\
\hline Croatia & 2569 & 1.24 & 18,597 & 1.66 \\
\hline Hungary & 3467 & 1.67 & 17,572 & 1.56 \\
\hline Ireland & 147 & 0.07 & 398 & 0.04 \\
\hline Italy & 34,991 & 16.85 & 196,034 & 17.45 \\
\hline Netherlands & 473 & 0.23 & 1319 & 0.12 \\
\hline Poland & 17,132 & 8.25 & 65,696 & 5.85 \\
\hline Portugal & 8769 & 4.22 & 50,507 & 4.50 \\
\hline Romania & 7218 & 3.48 & 38,019 & 3.38 \\
\hline Sweden & 4295 & 2.07 & 28,849 & 2.57 \\
\hline Slovenia & 1959 & 0.94 & 13,753 & 1.22 \\
\hline Slovakia & 2030 & 0.98 & 11,167 & 0.99 \\
\hline Total & 207,689 & 100 & $1,123,360$ & $100 \%$ \\
\hline
\end{tabular}




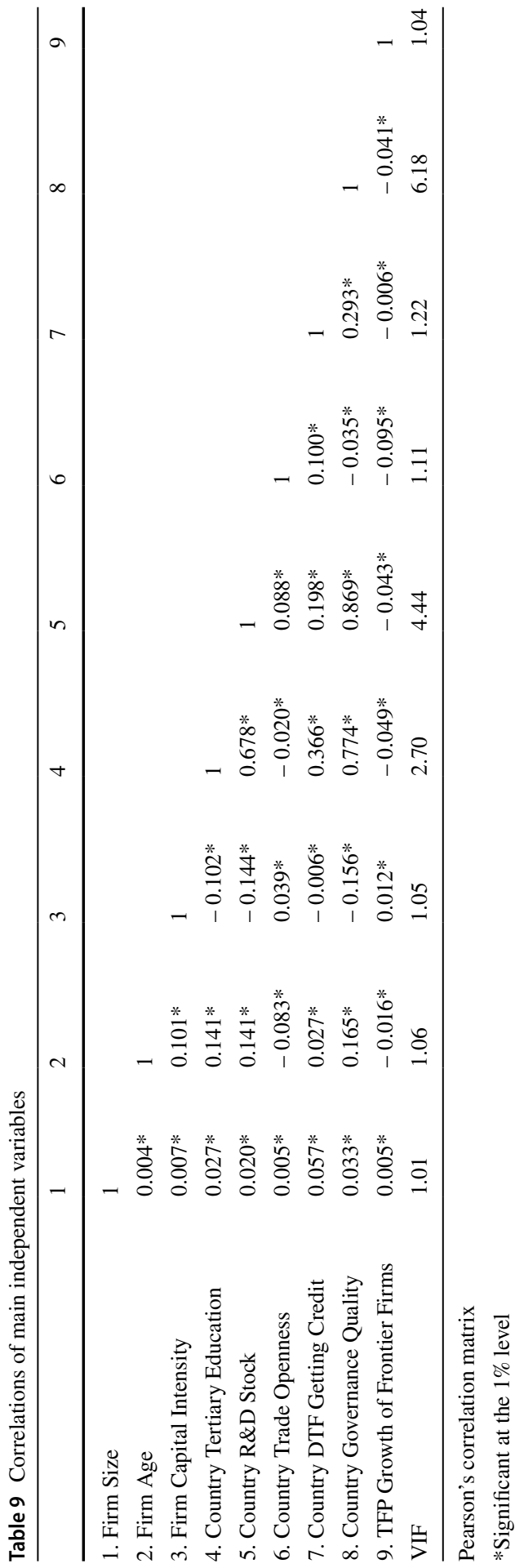


Acknowledgements We also acknowledge comments and suggestions from two anonymous reviewers and participants at the $15^{\text {th }}$ International Industrial Organization Conference (IIOC 2017, Boston), the XX Encuentro de Economía Aplicada (2017, Valencia), the $15^{\text {th }}$ European Workshop on Efficiency and Productivity Analysis (EWEPA, 2017, London), the 42nd Simposio de la Asociación Española de Economía-Spanish Economic Association (SAEe, 2017, Barcelona), the 45th European Association for Research in Industrial Economics (EARIE, 2018, Athens) and the 86th International Atlantic Economic Conference (IAES, 2018, New York). The usual disclaimer applies.

Funding Open Access funding provided thanks to the CRUE-CSIC agreement with Springer Nature. Financial support under Framework contract ENTR/300/PP/2013/FC-WIFO is gratefully acknowledged. The content of this paper does not reflect the official opinion of the European Commission. We further acknowledge financial support from Grant ECO2017-86793-R funded by MCIN/ AEI/10.13039/501100011033 and by "ERDF A way of making Europe" and from the Generalitat Valenciana (PROMETEO /2019/095). Responsibility for the information and views expressed in this paper lies entirely with the authors.

Open Access This article is licensed under a Creative Commons Attribution 4.0 International License, which permits use, sharing, adaptation, distribution and reproduction in any medium or format, as long as you give appropriate credit to the original author(s) and the source, provide a link to the Creative Commons licence, and indicate if changes were made. The images or other third party material in this article are included in the article's Creative Commons licence, unless indicated otherwise in a credit line to the material. If material is not included in the article's Creative Commons licence and your intended use is not permitted by statutory regulation or exceeds the permitted use, you will need to obtain permission directly from the copyright holder. To view a copy of this licence, visit http://creativecommons.org/licen ses/by/4.0/.

\section{References}

Acemoglu, D., Aghion, P., Lelarge, C., Van Reenen, J., \& Zilibotti, F. (2007). Technology, information and the decentralization of the firm. Quarterly Journal of Economics, 122, 1759-1799.

Acemoglu, D., Aghion, P., \& Zilibotti, F. (2006). Distance to frontier, selection and economic growth. Journal of the European Economic Association, 4, 37-74.

Acemoglu, D., Johnson, S., \& Robinson, J. A. (2002). Reversal of fortune: Geography and institutions in the making of the modern world income distribution. Quarterly Journal of Economics, 117(4), 1231-1294.

Adalet McGowan, M., Andrews, D., \& Millet, V. (2017). The Walking Dead? Zombie Firms and Productivity Performance in OECD Countries. OECD Economics Department Working Paper No. 1372.

Aghion, P., Bloom, N., Blundell, R., Griffith, R., \& Howitt, P. (2005). Competition and innovation: An inverted-U relationship. Quarterly Journal of Economics, 120, 701-728.

Aghion, P., Burgess, R., Redding, S., \& Zilibotti, F. (2008). The Unequal effects of liberalization: Evidence from dismantling the license Raj in India. American Economic Review, 98, 1397-1412.

Agostino, M., Di Tommaso, M. R., Nifo, A., Rubini, L., \& Trivieri, F. (2020). Institutional quality and firms' productivity in European regions. Regional Studies, 54(9), 1275-1288.

Alguacil, M., Cuadros, A., \& Orts, V. (2011). Inward FDI and growth: The role of macroeconomic and institutional environment. Journal of Policy Modeling, 33(3), 481-496.

Alvarez, R., \& Crespi, G. (2007). Multinational firms and productivity catching-up: The case of Chilean manufacturing. International Journal of Technological Learning, Innovation and Development, 1 , 136-152.

Amable, B., Demmou, L., \& Ledezma, I. (2010). Product Market Regulation, Innovation, and Distance to Frontier. Industrial and Corporate Change, 19, 117-159.

Amiti, M., \& Konings, J. (2007). Trade liberalization, intermediate inputs, and productivity: Evidence from Indonesia. The American Economic Review, 97, 1611-1638.

Andrews, D., Criscuolo, C., \& Gal, P. N. (2015). Frontier Firms, technology diffusion and public policy: Micro evidence from OECD Countries. OECD Productivity Working Papers 2, OECD Publishing. 
Andrews, D., Criscuolo, C., \& Gal, P. N. (2016). The global productivity slowdown, technology divergence and public policy: a firm-level perspective. Hutchins Center Working Papers 24, Brookings.

Añón-Higón, D., Máñez, J. A., Rochina-Barrachina, M. E., Sanchis, A., \& Sanchis, J. A. (2018). The impact of the Great Recession on TFP convergence among EU countries. Applied Economics Letters, 25, 393-396.

Arnold, J.M., Nicoletti, G., \& Scarpetta, S. (2008). Regulation, Allocative Efficiency and Productivity in OECD Countries: Industry and Firm-Level Evidence. OECD Economics Department Working Papers 616, OECD Publishing.

Barro, R. J., \& Sala-i-Martín, X. (1992). Convergence. Journal of Political Economy, 100, 223-251.

Bartelsman, E., Dobbelaere, S., \& Peters, B. (2015). Allocation of human capital and innovation at the frontier: Firm-level evidence on Germany and the Netherlands. Industrial and Corporate Change, 24, 875-949.

Bartelsman, E., Haskel, J., \& Martin, R. (2008). Distance to Which Frontier? Evidence on Productivity Convergence from International Firm-level Data. CEPR Discussion Papers No. 7032.

Bartelsman, E., Haltiwanger, J., \& Scarpetta, S. (2013). Cross country differences in productivity: The role of allocation and selection. American Economic Review, 103, 305-334.

Beneito, P., Coscollá-Girona, P., Rochina-Barrachina, M. E., \& Sanchis, A. (2015). Competitive pressure and innovation at the firm level. Journal of Industrial Economics, 63, 422-457.

Beneito, P., Rochina-Barrachina, M. E., \& Sanchis, A. (2014). Patents, Competition, and Firms' Innovation Incentives. Industry and Innovation, 21(4), 285-309.

Beneito, P., Rochina-Barrachina, M. E., \& Sanchis, A. (2017). Competition and innovation with selective exit: An inverted-U shape relationship? Oxford Economic Papers, 69, 1032-1053.

Børing, P. (2019). The relationship between firm productivity, firm size and CSR objectives for innovations. Eurasian Business Review, 9(3), 269-297.

Cabrales, A., Dolado, J.J., \& Mora, R. (2014). Dual Labour Markets and (Lack of) On-the-Job Training: PIAAC Evidence from Spain and Other EU Countries. IZA DP No. 8649.

Calero, J., Murillo Huertas, I.P., \& Raymond, J. (2016), Education, Age and Skills: An Analysis Using the PIAAC Survey. IEB Working Paper N. 2016/03.

Campos, N. F., Estrin, S., \& Proto, E. (2010). Corruption as a barrier to entry: Theory and evidence. CEPR Discussion Paper No. DP8061.

Castellani, D., Piva, M., Schubert, T., \& Vivarelli, M. (2019). R\&D and productivity in the US and the EU: Sectoral specificities and differences in the crisis. Technological Forecasting and Social Change, 138, 279-291.

Cette, G., Fernald, J., \& Mojon, B. (2016). The pre-Great Recession slowdown in productivity. European Economic Review, 88, 3-20.

Chatterjee, S., Hadi, A. S., \& Price, B. (2000). Regression analysis by example. Wiley.

Chowdhury, F., \& Audretsch, D. B. (2014). Institution as looting apparatus: Impact of Gender Equality and Institutions on Female Entrepreneurship. Eurasian Business Review, 4(2), 207-225.

Conway, P., Meehan, L., \& Zheng, G. (2015). Do New Zealand Firms Catch up to the Domestic Productivity Frontier?. New Zealand Productivity Commission Working Paper 2015/3.

Crescenzi, R., Di Cataldo, M., \& Rodriguez-Pose, A. (2016). Government quality and the economic returns of transport infrastructure investment in European regions. Journal of Regional Science, 56(4), 555-582.

Decker, R. A., Haltiwanger, J., Jarmin, R. S., \& Miranda, J. (2016). Declining business dynamism: What we know and the way forward. American Economic Review, 106, $203-207$.

Dias, D.A., Robalo Marques, C., \& Richmond, C. (2014). Resource Allocation, Productivity and Growth in Portugal. Economic Bulletin and Financial Stability Report Articles, Bank of Portugal.

Ding, S., Sun, P., \& Jiang, W. (2016). The effect of import competition on firm productivity and innovation: Does the distance to technology frontier matter? Oxford Bulletin of Economics and Statistics, 78, 197-227.

Ezcurra, R., \& Rios, V. (2019). Quality of government and regional resilience in the European Union. Evidence from the Great Recession. Papers in Regional Science, 98, 1267- 1290.

Färe, R., Grosskopf, S., \& Margaritis, D. (2006). Productivity growth and convergence in the European Union. Journal of Productivity Analysis, 25, 111-141.

Fernandes, A. M. (2007). Trade policy, trade volumes and plant-level productivity in Colombian manufacturing industries. Journal of International Economics, 71, 52-71.

Gal, P. N. (2013). Measuring Total Factor Productivity at the Firm Level using OECD-ORBIS. Economics Department Working Papers Nº 1049, OECD. 
Gill, I. S., \& Raiser, M. (2012). Golden growth: Restoring the lustre of the European economic model. World Bank Publications.

Gogokhia, T., \& Berulava, G. (2021). Business environment reforms, innovation and firm productivity in transition economies. Eurasian Business Review, 11, 221-245.

Gopinath, G., Kalemli-Ozcan, S., Karabarbounis, L., \& Villegas-Sanchez, C. (2017). Capital allocation and productivity in South Europe. The Quarterly Journal of Economics, 132, 1915-1967.

Griffith, R., Redding, S., \& Van Reenen, J. (2004a). Mapping the two faces of R\&D: Productivity growth in a panel of OECD industries. Review of Economics and Statistics, 86, 883-895.

Griffith, R., Redding, S., \& Simpson, H. (2004b). Foreign ownership and productivity: New evidence from the service sector and the R\&D lab. Oxford Review of Economic Policy, 20, 533-564.

Hoftijzer, M., \& Gortazar, L. (2018). Skills and Europe's Labor Market: How technological change and other drivers of skill demand and supply are shaping Europe's Labor market. World Bank Report on the European Union. World Bank Group.

Honing, A. (2008). Do improvements in government quality necessarily reduce the incidence of costly sudden stops? Journal of Banking and Finance, 32(3), 360-373.

Hsieh, C., \& Klenow, P. (2009). Misallocation and manufacturing TFP in China and India. Quarterly Journal of Economics, 124, 1403-1448.

Iacovone, L., \& Crespi, G. (2010). Catching-up with the technological frontier: Micro-level evidence on growth and convergence. Industrial and Corporate Change, 19, 2073-2096.

Jankauskas, V., \& Seputiene, J. (2007). The relation between social capital. Governance and Economic Performance in Europe, Business: Theory and Practice, 8(3), 131-138.

Jovanovic, B. (1982). Selection and the evolution of industry. Econometrica, 50, 649-670.

Kaasa, A. (2016). Social capital, institutional quality and productivity: Evidence from European regions. Economics \& Sociology, 9(4), 11.

Kalemli-Ozcan, S., Sorensen, B., Villegas-Sánchez, C., Volosovych, V., \& Yesiltas, S. (2015), How to Construct Nationally Representative Firm Level Data from the Orbis Global Database. NBER Working Papers 21558, National Bureau of Economic Research, Inc.

Kaufmann, D., Kraay, A., \& Mastruzzi, M. (2010). The Worldwide Governance Indicators: Methodology and Analytical Issues. World Bank Policy Research Working Paper, No. 5430.

Kneller, R., \& Stevens, P. A. (2006). Frontier technology and absorptive capacity: Evidence from OECD manufacturing industries. Oxford Bulletin of Economics and Statistics, 68, 1-21.

Kumbhakar, S. C., Ortega-Argilés, R., Potters, L., Vivarelli, M., \& Voigt, P. (2012). Corporate R\&D and firm efficiency: Evidence from Europe's top R\&D investors. Journal of Productivity Analysis, 37(2), 125-140.

Lasagni, A., Nifo, A., \& Vecchione, G. (2015). Firm productivity and institutional quality: Evidence from Italian industry. Journal of Regional Science, 55(5), 774-800.

Levinsohn, J., \& Petrin, A. (2003). Estimating production functions using inputs to control for unobservables. Review of Economic Studies, 70, 317-342.

Melitz, M. J. (2003). The impact of trade on intra-industry reallocations and aggregate industry productivity. Econometrica, 71, 1695-1725.

Mimicopoulos, M., Kyj, L., Sormani, N., Bertucci, G., \& Qian, H. (2007). Public governance indicators: A literature review. New York: United Nations Department of Economic and Social Affairs.

Nistotskaya, M., Charron, N., \& Lapuente, V. (2015). The wealth of regions: Quality of government and SMEs in 172 European regions. Environment and Planning C: Government and Policy, 33(5), 1125-1155.

OECD. (2017). OECD G20 policy paper on economic resilience and structural policies. OECD.

Olley, S., \& Pakes, A. (1996). The dynamics of productivity in the telecommunications equipment industry. Econometrica, 64, 1263-1298.

Restuccia, D., \& Rogerson, R. (2008). Policy distortions and aggregate productivity with heterogeneous establishment. Review of Economic Dynamics, 11, 707-720.

Ridao-Cano, C., \& Bodewig, C. (2018). Growing united: Upgrading Europe's convergence machine: Overview. World Bank Group.

Rios, V., \& Gianmoena, L. (2020). The link between quality of government and regional resilience in Europe. Journal of Policy Modeling, 42, 1064-1084.

Rodríguez-Pose, A., \& Di Cataldo, M. (2015). Quality of government and innovative performance in the regions of Europe. Journal of Economic Geography, 15(4), 673-706.

Rodrik, D., Subramanian, A., \& Trebbi, F. (2004). Institutions rule: The primacy of institutions over geography and integration in economic development. Journal of Economic Growth, 9(2), 131-165. 
Sala-i-Martín, X. (1996). Regional cohesion: Evidence and theories of regional growth and convergence. European Economic Review, 40, 1325-1352.

Shu, P., \& Steinwender, C. (2018). The impact of trade liberalization on firm productivity and innovation. NBER Working Papers 24715, National Bureau of Economic Research, Inc.

Sondermann, D. (2014). Productivity in the Euro area: Any evidence of convergence? Empirical Economics, 47, 999-1027.

Sondermann, D. (2018). Towards more resilient economies: The role of well-functioning economic structures. Journal of Policy Modeling, 40(1), 97-117.

Syverson, C. (2011). What determines productivity? Journal of Economic Literature, 49, 326-365.

Van der Wiel, H., Creusen, H., Van Leeuwen, G., \& Van der Pijll, E. (2012). The Dutch productivity performance: cross your border and look around. In M. Mas \& R. Stehrer (Eds.), Industrial productivity in Europe: Growth and crisis. Edward Elgar Publishing.

Villaverde, J., \& Maza, A. (2008). Productivity convergence in the European regions, 1980-2003: A sectoral and spatial approach. Applied Economics, 40, 1299-1313.

Wooldridge, J. M. (2009). On estimating firm-level production functions using proxy variables to control for unobservables. Economics Letters, 104, 112-114.

Publisher's Note Springer Nature remains neutral with regard to jurisdictional claims in published maps and institutional affiliations. 